\title{
Changes in PBM Business Practices in 2019: True Innovation or More of the Same?
}

\author{
Brenda R. Motheral, RPh, MBA, PhD, and Kathleen A. Fairman, MA, PhD
}

\section{SUMMARY}

In 2019, pharmacy benefit managers (PBMs) responded to intense public criticism with business model changes described as movements toward full transparency and innovation to reduce costs for benefit plan sponsors. We critically analyze these changes in light of key challenges in specialty drug management: pharmaceutical manufacturer practices (price increases driven by coverage mandates and lack of price control, intensive and sometimes misleading advertising, patent extensions), FDA changes (increased reliance on manufacturer funding, weakened evidentiary base for drug approvals), and provider prescribing patterns (lag from evidence to routine practice, manufacturer influences on the knowledge base, direct manufacturer payments to frequent prescribers).

The persistence of controversial PBM practices suggests that business model changes were mostly cosmetic, without altering key marketplace dysfunctions. Examples include "spread" pricing, in which PBMs pay pharmacies less than employer-paid amounts; rebate-influenced formulary development; and shifting of prescription volume to PBM-owned pharmacies. Spread in Medicaid was estimated at \$224.8 million in Ohio and $\$ 123.5$ million in Kentucky in 1-year periods and is the subject of an ongoing federal investigation. Rebate influence on formulary development is suggested by slow biosimilar adoption and a study documenting little association between brand exclusions and clinical or cost-effectiveness. Even in $100 \%$ passthrough arrangements, the price differential between rebated products and lower-cost alternatives may far exceed revenues returned to the payer. Shifting of business to PBM-owned pharmacies was identified in Florida managed Medicaid in 2018, where the state's 5 largest specialty pharmacies, all owned by managed care organizations or PBMs, collected $28 \%$ of prescription drug profit despite dispensing only $0.4 \%$ of claims. Finally, contract provisions and terms typically limit the ability of plan sponsors to monitor PBM performance. These include "offsetting," changes in definitions (e.g., "single-source generic") during the contract term, restrictions on audit rights, and exclusion of some pharmaceutical manufacturer revenues from " $100 \%$ " passthroughs. We conclude that ostensibly positive changes in PBM practices have been offset by undisclosed business arrangements, shifts to alternative revenue sources, and opaque contractual terms. Establishing and maintaining a sustainable benefit will require fundamental alterations to this dysfunctional market

J Manag Care Spec Pharm. 2020;26(10):1325-33

Copyright $\odot 2020$, Academy of Managed Care Pharmacy. All rights reserved.
$\mathrm{F}$ or the pharmacy benefit management (PBM) industry, 2019 was widely viewed as a watershed year of business model changes brought about by disruptive competition; new federal and state regulations; intense public scrutiny; and accusations of business practices that represent, as described by one U.S. senator, as "one of the most gnarled, confounding riddles in American health care."1-5 In this critical review of peer-reviewed and grey literature, we conclude that these changes were (1) mostly cosmetic rather than fundamentally altering key dysfunctions in PBM-client relationships, and (2) insufficient to address the most pressing challenge facing benefit plan sponsors today: management of the specialty drug benefit. We focus on specialty drugs as a high-stakes financial concern, ${ }^{6}$ with many employers viewing escalating costs as an existential threat to health benefits, and an estimated 30\% considering new plans or PBMs. ${ }^{7,8}$ Equally high stakes are clinical challenges stemming from common uses, such as off-label prescribing and genomic therapy for patients without the targeted mutation, that are clinically questionable or potentially harmful. ${ }^{9-12}$ Following a description of PBM industry foundations, we consider specific drivers of these benefit-management challenges and conclude with a critical assessment of the PBM industry's response to them.

\section{Foundation of Drug Benefit Management in Early PBM Business Models}

Contracting with a PBM provided important advantages for employers in the 1980s and 1990s, including administrative efficiencies from pharmacy carve-outs and automated claims processing, and favorable discounts off average wholesale price in PBM mail order. ${ }^{13,14}$ Employer-PBM arrangements began to shift toward greater PBM influence as drug spending increased rapidly beginning in the 1990s, fueled by "blockbuster" drug launches, coverage expansions, and increasingly broad definitions of chronic disease. ${ }^{15-17}$ Employers and other plan sponsors gradually relinquished control of the benefit, making decisions about design features (e.g., copayments, deductibles) but delegating key business arrangements like network contracting, price negotiation, formulary coverage, and utilization management to the PBM..$^{13,18}$

More recently, double-digit specialty drug cost increases and concerns about the transparency of PBM business practices led to growing consensus that this delegated model was no longer working well for many employers and patients. . $3,5,13,19^{\text {Recent }}$ 
initiatives publicized by some PBMs in response to these concerns include collaborative employer-PBM arrangements described as transparent cost passthroughs building on previous movements toward transparency; innovative manufacturer contracts (e.g., "value-based" coverage, long-term payment plans); new clinical performance requirements; increased formulary exclusions for brand drugs; and increased biosimilar use., ${ }^{4,20-23}$ Although potentially positive, these changes should be understood in the context of 3 challenges, or "headwinds," in specialty drug management: pharmaceutical manufacturer practices, U.S. Food and Drug Administration (FDA) changes, and provider prescribing patterns.

\section{Headwind \#1: Pharmaceutical Manufacturer Practices}

Employers, which lack leverage over drug pricing and regulation, must rely on PBMs and consultants to combat several sources of manufacturer-related cost increases (Table 1 , Box A) ${ }^{24-54}$ Among these are much higher prices for prescription medications in the United States than in other countries, such as the United Kingdom. ${ }^{24}$ For example U.S. prices (in 2014 dollars) were higher by $96 \%$ for adalimumab (2 syringes, $\$ 2,669$ vs. $\$ 1,362$, respectively), $42 \%$ for ledipasvir-sofosbuvir (4-week supply, $\$ 32,114$ vs. $\$ 22,554$ ), and $736 \%$ for bevacizumab (400 mg, $\$ 3,930$ vs. $\$ 470) .{ }^{25}$

Critical to understanding these price differentials is the economic principle that pricing is based on "what the market will bear," not on the producer's cost. ${ }^{26,27}$ When payers lack leverage to negotiate, producers lack incentive to be pricecompetitive. ${ }^{28}$ Passage of the Affordable Care Act, which eliminated lifetime benefit maximums, mandated coverage in every U.S. Pharmacopeia class, and included no price controls, was soon followed by large price increases for specialty drugs. ${ }^{29-31}$ Similarly, broad coverage requirements may leave publicly funded health care programs with little leverage against price increases. ${ }^{28}$ For example, total Medicare spending on repository corticotropin, a pediatric antiseizure medication with limited effectiveness over less costly alternative medications in adults, increased nearly 13-fold, from \$49.5 million in 2011 to $\$ 636$ million in 2016, with the cost per claim increasing from $\$ 33,621$ to $\$ 49,442$ during that period. ${ }^{32-36}$ In contrast to these U.S. circumstances, most other countries use price regulations (e.g., reference pricing, health technology assessment) to control drug costs. ${ }^{37}$

Additional manufacturer practices increase U.S. payer outlays. Manufacturer expenditures on U.S. direct-to-consumer advertising (DTCA) for prescription drugs-legally prohibited in all other countries except New Zealand-more than quadrupled, from $\$ 1.3$ billion (79,000 advertisements) in 1997 to $\$ 6$ billion (4.6 million advertisements) in 2016. ${ }^{38,39}$ Deceptive advertising, sometimes resulting in substantial financial settlements with the U.S. Department of Justice to resolve allegations of wrongdoing, also impairs effective management. ${ }^{40-45}$ Patent extensions facilitated by congressional actions intended to encourage drug development have delayed launches of FDAapproved biosimilars, with 16 launched and 10 unlaunched as of March 2020.46-51 Allegations of anticompetitive practices, including requirements for biosimilar exclusions to obtain single-source brand rebates, "fail-first" provisions, and misleading advertising about biosimilar safety and efficacy, are under litigation and may contribute to markedly reduced U.S. market penetration compared with the European Union (e.g., $15 \%$ vs. $71 \%$, respectively, for infliximab biosimilars). ${ }^{52-54}$

\section{Headwind \#2: FDA Changes}

Although consultants and PBMs have historically relied on FDA approval as sufficient evidence for coverage, the wisdom of that approach is challenged by questions about whether programs intended to promote clinical innovation have compromised the agency's regulatory function (Table 1, Box B) ${ }^{46,55-62}$ Manufacturer fees from the Prescription Drug User Fee Act and other programs increased from $\$ 36.3$ million in 1993 to $\$ 1.38$ billion in 2019, respectively, funding 29\% and 66\% of the FDA's total budget for human drug and biologic applications in those years. ${ }^{56,57}$

Simultaneously, the evidentiary basis for drug approvals has weakened per provisions of breakthrough and accelerated approval pathways, with percentages based on uncontrolled studies increasing from $4 \%$ to $17 \%$ and on active-comparator studies declining from 44\% to $29 \%$ from 1995-1997 to 2015-2017.58 Weaker evidence was particularly normative for drugs with a Breakthrough Therapy designation, for which $52 \%$ of approvals from 2013-2016 were based only on phase 1 or phase 2 trials. ${ }^{58}$ Similarly, accelerated drug approval may be based on a surrogate, such as tumor shrinkage, that "is reasonably likely to predict" clinical benefit, provided that the manufacturer agrees to postmarketing studies of an endpoint outcome. ${ }^{59}$ However, these surrogate-based approvals may yield limited evidence of clinical benefit in controlled research. ${ }^{60,61}$ For example, among surrogate-based oncology drug approvals from 2008-2012, only 14\% of drugs improved survival, $50 \%$ did not, and $36 \%$ were untested after a median of 4.4 postapproval years. ${ }^{61}$ For payers, these changes mean that specialty drugs may not consistently represent good value for money spent. Compounding this issue, the FDA has no legal authority to investigate cost-effectiveness. ${ }^{62}$

\section{Headwind \#3: Provider Prescribing Patterns}

Payers may experience challenges resulting from the "evidence to practice gap," defined as inconsistency between available scientific evidence and clinical practice that has persisted for decades (Table 2, Box A). ${ }^{10-12,63-76}$ The estimated 17-year lag time between translational (application-oriented) research and routine care contributes to sometimes clinically questionable utilization. ${ }^{10-12,65-67}$ Examples include pegfilgrastim for 


\section{TABLE 1 "Headwinds" in Specialty Drug Management, U.S. Level}

\section{Box A. Pharmaceutical Manufacturer Practices}

No leverage over price

- Prices higher in United States, no price control mechanisms24,25,37

- Prices rose sharply after ACA implementation, "what the market will bear"26-31

Demand fueled by DTCA 39

- DTCA ad buys were $\$ 1.3$ billion in 1997, $\$ 6$ billion in 2016

- DTCA increases use of promoted products

- DTCA emphasis is on brand drug, not lifestyle or generic products

Potentially misleading marketing

- Failure to warn of potential for fatal overdose in ad for ER injectable for opioid addiction 40

- Downplaying of ADEs in marketing materials for injectable drug for plaque psoriasis ${ }^{41}$

- Failure to mention any risk information in pediatric-targeted advertisement for stimulant with black-box warning for abuse potential ${ }^{42}$

- Website statement that investigational monoclonal antibody was a cure for brain cancer and was "safe and effective," although drug was not approved 43

- Financial settlements (manufacturer names not shown):

- $\$ 2.2$ billion to resolve allegations of fraudulent off-label promotion and "kickbacks" to physicians and pharmacists ${ }^{44}$

- $\$ 1.4$ billion to resolve criminal and civil liability for "illicit" promotion of buprenorphine-naloxone ${ }^{45}$

- 103 settlements totaling > \$1l billion from 1997-2016 for unlawful (typically off-label) promotion ${ }^{39}$

Patent extensions, delayed biosimilar launches

- Adalimumab (5 approved biosimilars, no launches expected until 2023)51

- Infliximab (4 approved biosimilars, 2 launched as of February 2020)48

- Etanercept (2 approved biosimilars, expected launch dates unknown)48,51

- Biosimilar market shares in the United States vs. European Union, respectively ${ }^{54}$

- Filgrastim: $94 \%$ vs. $72 \%$

- Infliximab: $71 \%$ vs. $15 \%$

- Pegfilgrastim: $42 \%$ vs. $29 \%$

\section{Box B. FDA Changes}

Increases in pharmaceutical manufacturer funding

- Fees as percentage of total FDA budget for human drug and biologics regulation

- FY 1993: PDUFA was $\$ 36,319,490$ of $\$ 126,958,144(29 \%)^{56}$

- FY 2019: All fees (PDUFA, generic, biosimilars, facility) were $\$ 1.38$ billion of $\$ 2.1$ billion $(66 \%)^{57}$

Weakened base of evidence from 1995-1997 to 2015-201758

- Uncontrolled studies increased from $4 \%$ to $17 \%$ of approvals

- Active-comparator studies declined from $44 \%$ to $29 \%$ of approvals

- $52 \%$ of breakthrough drug approvals based only on phase 1 or 2 trials; $42 \%$ based on no controlled studies in 2013-2016

Approvals based on surrogates and biomarkers

- No significant difference between breakthrough and non-breakthrough oncology drugs on tumor response rate (37\% vs. 39\%), MOA (36\% vs. 39\%), ADEs ( $38 \%$ vs. $36 \%$ ), or death ( $6 \%$ vs. $4 \%)^{60}$

- $67 \%$ of oncology drugs in 2008-2012 approved based on surrogate endpoint, follow-up median of 4.4 years after approval ${ }^{61}$

of those, RCTs showed 14\% improved survival, $50 \%$ did not, and 36\% not tested

$\circ$ Surrogate basis much more likely (100\%) for accelerated approval

$A C A=$ Affordable Care Act; $A D E=$ adverse drug event; DTCA = direct-to-consumer advertising; ER=extended-release; FDA =U.S. Food and Drug Administration; $F Y=$ fiscal year; $M O A=$ mechanism of action; PDUFA = Prescription Drug User Fee Act; $R C T=$ randomized controlled trial.

low- or intermediate-risk chemotherapy without other risk factors $(46 \%)^{11}$; off-label oral oncolytics without evidentiary support $(3 \%)^{66}$; and proprotein convertase subtilisin/kexin 9 inhibitors off-label (12\%) or without concomitant statin use (60\%). ${ }^{67}$ Physicians may also lack awareness of drug costs. ${ }^{68,69}$

Although gaps in available evidence (e.g., when studies exclude patients with common comorbidities) contribute to the problem, the sometimes-conflicted relationships between physicians and the pharmaceutical industry also play a role..$^{70-72}$ Despite Sunshine Act disclosure requirements, concerns remain about manufacturer influences on knowledge dissemination, such as "gift authorship" arrangements, research targeted to commercial interests, and "detailing" visits. ${ }^{72-74}$

Studies consistently document decreased prescribing costeffectiveness from these practices-an important issue because an estimated $48 \%$ of U.S. physicians received payments totaling $\$ 2.4$ billion from drug and device manufacturers in $2015 .{ }^{73,74}$ In Medicare Part D, receipt of even a single manufacturer-funded meal (mean value $<\$ 20$ ) was associated with increases of $18 \%-118 \%$ in odds of prescribing branded drugs when less 


\section{TABLE 2 "Headwinds" in Specialty Drug Management, Provider and PBM Level}

Box A. Provider Practice Patterns

Clinical practice lagging behind science

- Estimated 17-year lag from translational research to routine care adoption 65

- Examples of studies documenting clinically questionable prescribing:

- 46\% of pegfilgrastim doses for patients using low- or intermediate-risk chemotherapy unnecessary ${ }^{11}$

- $29 \%$ of high-cost oral oncolytic uses off-label; of those, $12 \%$ not supported $(12 \% \text { of } 29 \%=3 \%)^{66}$

- 12\% of early PCSK9-I uses were off-label; concomitant statin used by $40 \%$ (i.e., $60 \%$ did not use statins) ${ }^{67}$

Aggregated estimated costs associated with clinically inappropriate uses

- $>$ \$112,000 in 1 year in a single hospital study of 292 patients treated with CSF in 2009-201011

- $\$ 2.5$ billion nationwide for use of chemotherapies not supported by evidence in $2010^{10}$

Lack of drug price awareness

- Physicians unaware of drug costs; overestimate lower-cost drugs; underestimate higher-cost drugs 68,69

Manufacturer influence

- Receipt of a single manufacturer-funded meal increases brand prescribing75

- $88 \%$ of frequent repository corticotropin prescribers received manufacturer payments totaling $\$ 2.2$ million $^{76}$

\section{Box B. PBM Practices}

Manufacturer-derived revenue sources: Administrative fees, inflation adjustments, care-management fees, rebates, sales of claims data, inventory procurement fees ${ }^{77}$

Spread

Ohio Medicaid

- \$5.71 per script for all brands and generics, totaling \$224.8 million from April 2017-March $2018^{80}$

Kentucky Medicaid in 2018

- Spread was $58 \%$ of prescriptions; of $\$ 858$ million paid to PBMs, $\$ 123.5$ million retained as spread79

Massachusetts Medicaid ${ }^{82}$

- Highest 5 spreads mean per script: tacrolimus $(\$ 2,350)$, imatinib $(\$ 1,811)$, omeprazole/bicarbonate (\$525), ribavirin (\$514), sildenafil $(\$ 397)$

- Spread was $22 \%$ of total payments to PBMs in $2014,54 \%$ in 2016

- MCO exceeded FFS cost by a mean $\$ 15.97$ overall and by $\geq \$ 50$ for $9.9 \%$ of drugs in quarter 4,2018

- Highest 5 increases of MCO over FFS mean cost per script (generic): valganciclovir (\$1,134), capecitabine (\$871), entecavir (\$709), clobazam (\$575-\$694), budesonide (\$525)

Owned pharmacies (Florida Medicaid) ${ }^{83}$

- Little evidence of spread overall, but evidence that MCOs and PBMs maintained profitability with other mechanisms; may have redirected business to their owned pharmacies

Rebate influence on formulary development

- No association between clinical value or cost-effectiveness and formulary inclusion ${ }^{94}$

- Formulary inclusion of branded alternatives costing $>\$ 1,500 /$ month despite low-cost ingredients $86,89-91$

- Some employers reluctant to give up rebate guarantees, despite evidence of cost-ineffectiveness 5,100

Failed prior authorization

Archimedes examples, payer cost

- First-line use of omalizumab, a monoclonal antibody indicated for asthma only after failed inhaled corticosteroid treatment $(\$ 12,120)^{95}$

- Use of repository corticotropin injection for MS without previous steroid injection trial $(\$ 169,293)^{32-34}$

- Use of somatropin, indicated for idiopathic growth deficiency, in 2 children at 75th and 97th height percentile with no clinical growth deficiencies $(\$ 49,333)^{96}$

- Ustekinumab dispensed at dosage too high for weight $(\$ 48,058)$

Information asymmetry

- Few published analyses of PBM programs, even in programs described as transparent20,99,100

Contractual terms and nontransparencies favoring PBMs ${ }^{18,102-104}$

- Omission of information about revenue received from manufacturers or PBM-owned pharmacies

- Omission or manipulation during contract term of key definitions, such as single-source generics

- Omission or manipulation during contract term of "offsetting" provisions

- Limited right to audit or verify billing accuracy

CSF=colony-stimulating factor; FFS = fee-for-service; $M C O=$ managed care organization; $M S=$ multiple sclerosis; PBM = pharmacy benefit manager; $P C S K 9-I=$ proprotein convertase subtilisin/kexin 9 inhibitor. 
expensive options were available. ${ }^{75}$ A more costly example was identified in an analysis of frequent prescribers of repository corticotropin, of whom $88 \%$ had received manufacturer payments totaling $>\$ 2.2$ million in 2015 ; each $\$ 10,000$ payment increment was associated with a $7.9 \%$ increase in Medicare spending on the drug. ${ }^{76}$ Under these circumstances, encouraging cost-effective, evidence-based utilization has become an increasingly difficult task.

\section{Critical Analysis: Are PBMs Headwind or Tack?}

Faced with headwinds, a wise sailor takes a new tack-a changed angle of movement that, executed properly, permits progress. For payers, a key question is whether recent changes to PBM business models represent a headwind, perhaps in a different form than previously, or a tack that facilitates forward movement. Addressing this question requires consideration of financial alignment because money received from pharmacies and pharmaceutical manufacturers has supplanted claimsprocessing fees paid by plan sponsors as the primary PBM revenue source (Table 2, Box B). ${ }^{13,77-106}$ We consider the question of financial alignment in this section, examining recent evidence on several controversial PBM business practices.

"Spread," or the differential between drug acquisition costs billed to the payer versus paid by the PBM to the dispensing pharmacy, came to public attention in 2018 after what one industry observer described as "the audit that changed everything," which documented a total of $\$ 224.8$ million in spread paid by Ohio Medicaid in a 1-year period. ${ }^{79,80}$ The resulting concerns about spread prompted a federal investigation launched in April 2019 and similar investigations in other states, including Kentucky, Massachusetts, and Florida. ${ }^{79,81-83}$ In Massachusetts, spread for the top 20 generic drugs ranged from $\$ 107-\$ 2,350$ per prescription, and managed care organization (MCO) cost exceeded fee-for-service payments by $\$ 15.97$ per drug overall and by $\geq \$ 50$ for $9.9 \%$ of drugs (top 5 mean cost increases: $\$ 525-\$ 1,134){ }^{82}$ These findings suggest that even when spread arrangements are declared in contracts, they represent financial misalignment between PBM and payer interests because total costs may far exceed what would otherwise have been paid for equivalent dispensing services.

A second controversial practice was highlighted in the report on Florida Medicaid, which produced little evidence of spread but a concerning finding that PBMs looking to "transition away from spread pricing without sacrificing profitability" may have found alternative revenue-enhancement mechanisms. ${ }^{83}$ These included shifting of managed care prescription volume to the state's 5 largest specialty pharmacies, which together collected $28 \%$ of available managed Medicaid prescription drug profit despite dispensing only $0.4 \%$ of claims in $2018 .^{83}$ For the state's top 5 specialty pharmacies, all owned by MCOs or PBMs, perclaim profit on managed Medicaid was \$79-\$207 compared with \$2-\$4 in retail pharmacies. ${ }^{83}$ Such arrangements create inherent misalignment between the payer's financial interest, selection of the most cost-effective dispensing site, and that of a PBM that owns a specialty pharmacy.

Rebates paid from pharmaceutical manufacturers to PBMs in exchange for formulary inclusion may be one of the clearest manifestations of misalignment, even in 100\% rebate passthrough arrangements, because the price differential between rebated products and lower-cost alternatives may far exceed revenues returned to the payer. For example, a branded ibuprofen-famotidine combination costing approximately $\$ 2,600$ per claim is included in the formulary of at least 1 large PBM, which has a multimillion dollar rebate arrangement with the manufacturer, although both ingredients are available as generic products for a total of $<\$ 20.84-89$ Similar concerns have been raised about topical diclofenac and combination naproxen-esomeprazole, priced at approximately $\$ 1,500$ and $\$ 2,200$, respectively, for a 30 -day supply, and included on some PBM formularies, sometimes with utilization management restrictions (e.g., prior authorization [PA], quantity limits). ${ }^{86,90,91}$

With few exceptions, biosimilar uptake among PBMs has been slow. ${ }^{23,92,93}$ Formulary decisions on brand drugs, sometimes touted as innovative cost-saving measures, are often unrelated to clinical value and may be implemented for products without any available comparative evidence of clinical or cost-effectiveness, suggesting that rebates influence them., ${ }^{4,594}$

Because these arrangements incentivize greater utilization and higher-cost drugs, PA use may be lax. Audits conducted by Archimedes, a firm with which we are affiliated, commonly reveal high-cost, clinically inappropriate utilization, similar to the patterns described in peer-reviewed research described previously, in paid claims that underwent PA (examples in Table 2, Box B). ${ }^{95,96}$ Investigation of these uses, coupled with medical reviews conducted by board-certified specialists, revealed that physician offices sometimes attested in the PBM's PA process to clinical criteria not supported by the medical record. With few exceptions, specialty drug PA denial rates or outcomes are rarely reported, and stakeholder organizations have identified a need for reform around increased transparency and evaluation of these programs. ${ }^{97-99}$ Similarly, although contracting innovations (e.g., value-based coverage, long-term payment plans) may prove to be beneficial, no outcomes for these programs have been reported, even in organizational arrangements ostensibly centered around transparency. ${ }^{20,100}$

\section{Disclosure and Transparency in Payer-PBM Contracts}

In response to concerns about industry practices, PBM representatives have argued that payer uptake of available innovations is typically slow, perhaps because spread pricing and rebates offset other costs, such as administrative fees or premiums. ${ }^{5,22}$ Supporting this view are relatively low use rates for point-of-sale rebates to reduce out-of-pocket costs and 
the phenomenon of "rebate addiction," or payer reluctance to convert from rebated to fee-only models. ${ }^{100,101}$ However, information disadvantage in contracting and monitoring PBM performance may mean that even in "transparent" arrangements, such choices are less than fully informed. ${ }^{18,102-104}$

PBM contracts with payers typically lack important detail about revenue received from manufacturers and pharmacies, drug-pricing methods, and dispensing costs at PBM-owned versus community pharmacies. ${ }^{18,103,104}$ Without such information, plan sponsors may be unaware of financial misalignments, such as whether the pharmacy network has been chosen based on the lowest cost to the plan sponsor or the highest financial yield to the PBM. ${ }^{18}$ Plan sponsors may also be unaware that multiple sources of manufacturer revenue may be excluded from the $100 \%$ passthroughs they receive or that the PBM may use a separate group purchasing organization to aggregate and distribute rebates, potentially allowing additional revenue retention. ${ }^{103,105}$ Key definitions, such as what constitutes a "single-source generic," and provisions, such as whether the PBM can "offset" failure to meet one guarantee with success in another, may be omitted or manipulated during the contract term. $^{18,103,104}$

Contracts also typically allow plan sponsors limited opportunity to evaluate PBM performance. Audit rights may be restricted by fees, limits on frequency or data access, or constraints on choice of auditor, making monitoring difficult for all but the largest plan sponsors. ${ }^{18,102-104}$ Moreover, few PBMs provide drug-level rebate reporting, leaving plan sponsors unable to determine if drugs have been chosen based on rebates or cost-effectiveness.

Although plan sponsors may contract with consultants or brokers to advise them on PBM selection, advisors vary greatly in their PBM knowledge, with some having limited sophistication on the complexity of PBM contracting or have conflicts of interest because of undisclosed PBM affiliations., ${ }^{5,18,102}$ Health Rosetta, a benefits-advising certifying organization, requires disclosure of all revenue sources and recommends use of consultants who do not accept PBM commissions. ${ }^{106,107}$ However, adoption of the Health Rosetta model has been slow.

\section{Conclusions}

In this critical review, we suggested that ostensibly positive changes in PBM practices have been offset by undisclosed business arrangements, shifts to other revenue sources, and opaque contractual terms. The challenge plan sponsors face is best understood by "following the money" and understanding their limited leverage over conflicted revenue streams and information asymmetry. Establishing and maintaining a sustainable health care benefit will require fundamental alterations to this dysfunctional market.

\section{Authors}

BRENDA R. MOTHERAL, RPh, MBA, PhD, CEO, Archimedes, Brentwood, Tennessee, and KATHLEEN A. FAIRMAN, MA, PhD, President and Research Consultant, Kathleen Fairman LTD, Phoenix, Arizona.

AUTHOR CORRESPONDENCE: Brenda R. Motheral, RPh, MBA PhD, Archimedes, 278 Franklin Rd., Ste. 245, Brentwood, TN 37027. Tel.: 615.418.7200; Email: bmotheral@archimedesrx.com.

\section{DISCLOSURES}

This work was funded solely by Archimedes, with no external funding. Motheral is the CEO of Archimedes, a specialty drug management company, and EpiphanyRx, a PBM that provides alternatives to the business models described in this article. Fairman is a consultant to Archimedes.

\section{REFERENCES}

1. Wyden R. Wyden statement at Finance Committee Hearing on drug prices and pharmacy benefit managers. April 9, 2019. U.S. Senate Committee on Finance. Available at: https://www.finance.senate.gov/ imo/media/doc/040919\%20Wyden\%20Statement\%20at\%20Finance\%20 Committee\%20Hearing\%20on\%20Pharmacy\%20Benefit\%20Managers.pdf. Accessed August 17, 2020.

2. O'Reilly KB. Time to scrutinize PBMs' outsized role in Rx decision making. American Medical Association. June 10, 2019. Available at: https:// www.ama-assn.org/delivering-care/public-health/time-scrutinize-pbmsoutsized-role-rx-decision-making. Accessed August 17, 2020.

3. Welborn S, John P. Imagine there are no PBMs. It's easy if you try. Stat News. August 23, 2018. Available at: https://www.statnews.com/2018/08/23/ pbms-rebates-drug-purchasing/. Accessed August 17, 2020.

4. Desai S. Top 10 PBM industry macrotrends in $2019 \&$ what to expect in 2020. Decision Resources Group. January 13, 2020. Available at: https:// decisionresourcesgroup.com/blog/top-10-pbm-industry-macrotrends-2019expect-2020\%. Accessed August 17, 2020.

5. Vela L. Reducing wasteful spending in employers' pharmacy benefit plans. The Commonwealth Fund. August 30, 2019. Available at: https://www. commonwealthfund.org/publications/issue-briefs/2019/aug/reducing-wastefulspending-employers-pharmacy-benefit-plans. Accessed August 17, 2020.

6. Inserro A. Employers say specialty drugs a factor behind rising costs AJMC Center for Biosimilars. April 17, 2019. Available at: https://www. centerforbiosimilars.com/news/employers-say-specialty-drugs-a-factorbehind-rising-costs-. Accessed August 17, 2020.

7. Waddill K. Employers focus on high-cost claims, drug spending into 2020. Health Payer Intelligence. August 15, 2019. Available at: https:// healthpayerintelligence.com/news/employers-focus-on-high-cost-claimsdrug-spending-into-2020. Accessed August 17, 2020.

8. Reed T. National Business Group on Health execs offer 2020 outlook on uptick in virtual care, impact of Amazon. FierceHealthcare. January 14, 2020. Available at: https://www.fiercehealthcare.com/hospitals-healthsystems/national-business-group-health-leaders-offer-2020-outlook-activist. Accessed August 17, 2020.

9. American Society of Clinical Oncology. Ten things physicians and patients should question. 2019. Available at: https://www.choosingwisely.org/societies/ american-society-of-clinical-oncology/. Accessed August 17, 2020.

10. Conti RM, Bernstein AC, Villaflor VM, Schilsky RL, Rosenthal MB, Bach PB. Prevalence of off-label use and spending in 2010 among patentprotected chemotherapies in a population-based cohort of medical oncologists. J Clin Oncol. 2013;31(9):1134-39. doi:10.1200/JCO.2012.42.7252. 
11. Waters GE, Corrigan P, Gatesman M, et al. Comparison of pegfilgrastim prescribing practice to national guidelines at a university hospital outpatient oncology clinic. J Oncol Pract. 2013;9(4):203-06.

12. Saiyed MM, Ong PS, Chew L. Off-label drug use in oncology: a systematic review of literature. J Clin Pharm Ther. 2017;42(3):251-58. doi:10.1111/jcpt.12507.

13. Kaupp GS, Lynch SB. To regain control of drug costs, health plans must understand the road they've traveled. Medscape Cardiol. April 1, 2002. Available at: https://www.medscape.com/viewarticle/432389. Accessed August 17, 2020.

14. Berndt ER, Newhouse JP. Pricing and reimbursement in U.S. pharmaceutical markets. September 2010. HKS Faculty Research Working Paper Series RWP10-039. John F. Kennedy School of Government, Harvard University. Available at: https://dash.harvard.edu/handle/1/4450127. Accessed August 17, 2020.

15. Aitken M, Berndt ER, Cutler DM. Prescription drug spending trends in the United States: looking beyond the turning point. Health Aff (Millwood). 2009;28(1):w151-60

16. Frakt A. Something happened to U.S. drug costs in the 1990s. New York Times. November 12, 2018. Available at: https://www.nytimes. com/2018/11/12/upshot/why-prescription-drug-spending-higher-in-the-us. html. Accessed August 17, 2020.

17. Fairman KA, Curtiss FR. Does medicalization of life imperil health? Expanding indications for diagnosis and treatment of chronic "disease." J Manag Care Pharm. 2011;17(6):469-80. doi:10.18553/jmcp.2011.17.6.469.

18. Eickelberg HC. The prescription drug supply chain "black box": how it works and why you should care. American Health Policy Institute. 2015 Available at: http://www.americanhealthpolicy.org/Content/documents/ resources/December\%202015_AHPI\%20Study_Understanding_the_ Pharma_Black_Box.pdf. Accessed August 17, 2020.

19. Thomas K, Pollack A. Specialty pharmacies proliferate, along with questions. New York Times. July 15, 2015. Available at: http://www.nytimes. com/2015/07/16/business/specialty-pharmacies-proliferate-along-withquestions.html?_r=1. Accessed August 17, 2020.

20. Burns J. Large employers push back on PBMs. Managed Care. February 27, 2020. Available at: https://www.managedcaremag.com/archives/2019/12/ large-employers-push-back-pbms. Accessed August 17, 2020

21. Kolar M. Drug pricing in America: a prescription for change, part III. Prime Therapeutics. April 9, 2019. Available at: https://www.finance.senate. gov/download/04092019-kolar-testimony. Accessed August 17, 2020.

22. Miller S. Drug pricing in America: a prescription for change, part III. Cigna Corporation. April 9, 2019. Available at: https://www.finance.senate. gov/imo/media/doc/Cigna\%20ExpressScripts\%20Testimony\%20of\%20 Steven\%20Miller\%20MD.pdf. Accessed August 17, 2020.

23. Whalen J. Give up on biosimilars? Never! Prime Insights. February 20 2020. Available at: https://www.primetherapeutics.com/en/news/primeinsights/2020-insights/insights-2020-never-give-up-on-biosimilars.html Accessed August 17, 2020.

24. Kang S, DiStefano MJ, Socal MP, Anderson GF. Using external reference pricing in Medicare Part D to reduce drug price differentials with other countries. Health Aff (Millwood). 2019;38(5):804-11.

25. Kama R, Cox C, McDermott D. What are the recent and forecasted trends in prescription drug spending? February 20, 2019. Kaiser Family Foundation. Available at: https://www.healthsystemtracker.org/chartcollection/recent-forecasted-trends-prescription-drug-spending/\#item-start. Accessed August 17, 2020.

26. Mohammed R. How to find out what customers will pay. Harvard Business Review. September 7, 2012. Available at: https://hbr.org/2012/09/ how-to-find-out-what-customers-will-pay. Accessed August 17, 2020.

27. Entis L. Why does medicine cost so much? Here's how drug prices are set. Time. April 9, 2019. Available at: https://time.com/5564547/drug-pricesmedicine/. Accessed August 17, 2020.
28. Sachs RE. Delinking reimbursement. Minnesota Law Review. July 2018. Available at: http://www.minnesotalawreview.org/wp-content/uploads/2018/07/ Sachs_MLR.pdf?platform=hootsuite. Accessed August 17, 2020.

29. Hutchins VA, Samuels MB, Lively AM. Analyzing the Affordable Care Act: essential health benefits and implications for oncology. J Oncol Pract. 2013;9(2):73-7. doi:10.1200/JOP.2012.000881.

30. Cornell Law School, Legal Information Institute. 45 CFR § 156.122 prescription drug benefits. Available at: https://www.law.cornell.edu/cfr/ text/45/156.122. Accessed May 1, 2020.

31. Norman B, Karlin-Smith S. The one that got away: Obamacare and the drug industry. Politico. July 13, 2016. Available at: https://www.politico. com/story/2016/07/obamacare-prescription-drugs-pharma-225444. Accessed August 17, 2020.

32. Metersky ML. Is there any reliable clinical evidence to suggest that Acthar is more effective than other forms of corticosteroids in treating sarcoidosis and other diseases it is being marketed to treat? Chest. 2016;149(3):886. doi:10.1016/j.chest.2015.11.027.

33. Thompson AJ, Kennard C, Swash M, et al. Relative efficacy of intravenous methylprednisolone and ACTH in the treatment of acute relapse in MS. Neurology. 1989;39(7):969-71.

34. Duarte-Garcia A, Matteson E, Shan ND. Older drugs with limited trial evidence: are they worth the expense? The case of repository corticotropin marketed as H.P. Acthar gel. Ann Intern Med. 2019;170(11):791-92. doi:10.7326/M18-3513.

35. Drash W, Hernandez S, Kessler A. Medicare spent $\$ 2$ billion for one drug as the manufacturer paid doctors millions. CNN. June 29, 2018. Available at: https://www.cnn.com/2018/06/29/health/acthar-mallinckrodtmedicare-claims-doctor-payments/index.html. Accessed August 17, 2020

36. Hartung DM, Johnston K, Van Leuven S, et al. Trends and characteristics of US Medicare spending on repository corticotropin. JAMA Intern Med. 2017;177(11):1680-82. doi:10.1001/jamainternmed.2017.3631.

37. OECD. Pharmaceutical Innovation and Access to Medicines. Paris, France: OECD Publishing; 2018. Available at: https://www.oecd-ilibrary. org/docserver/9789264307391-en.pdf?expires $=1588354203 \&$ \&id=id\&accna me $=$ guest $\&$ checksum=9A2E493E4108AFDD485413E6A61B330F. Accessed August 17, 2020.

38. Menkes D. NZ needs to join the rest of the world and ban prescription medicine ads. The University of Auckland. October 3, 2019. Available at: https://www.auckland.ac.nz/en/news/2019/10/03/nz-needs-to-banprescription-medicine-ads.html. Accessed August 17, 2020.

39. Schwartz LM, Woloshin S. Medical marketing in the United States, 1997-2016. JAMA. 2019;321(1):80-96. doi:10.1001/jama.2018.19320.

40. U.S. Food and Drug Administration. FDA issues warning letter for not including the most serious risks in advertisement for medication-assisted treatment drug. December 11, 2019. Available at: https://www.fda.gov/ news-events/press-announcements/fda-issues-warning-letter-not-including-mostserious-risks-advertisement-medication-assisted. Accessed August 17, 2020.

41. Blankenship K. Novartis slaps J\&J with Tremfya lawsuit, claiming it 'cherry-picked' safety stats. FiercePharma. March 5, 2019. Available at: https://www.fiercepharma.com/marketing/novartis-calls-foul-j-j-s-tremfyapromos. Accessed August 17, 2020.

42. U.S. Food and Drug Administration. ANDA 040776, PROCENTRA® (dextroamphetamine sulfate) oral solution. Warning letter. February 21, 2020. Available at: https://www.fda.gov/media/135684/download. Accessed August 17, 2020.

43. U.S. Food and Drug Administration. Pritumumab. Letter. November 1 , 2019. Available at: https://www.fda.gov/media/132641/download. Accessed August 17, 2020.

44. U.S. Department of Justice. Johnson \& Johnson to pay more than $\$ 2.2$ billion to resolve criminal and civil investigations. November 4, 2013.

Available at: https://www.justice.gov/opa/pr/johnson-johnson-pay-more-22billion-resolve-criminal-and-civil-investigations. Accessed August 17, 2020 
45. U.S. Department of Justice. Current and recent cases. Prescription drugs and medical devices. Available at: https://www.justice.gov/civil/current-andrecent-cases\#_Pharm2. Accessed August 17, 2020.

46. Sharfstein JM. Reform at the FDA-in need of reform. JAMA. 2020;323(2):123-24. doi:10.1001/jama.2019.20538.

47. Brennan Z. Six lawsuits target AbbVie's Humira and its patent thicket. Regulatory Focus. April 2, 2019. Available at: https://www.raps.org/ news-and-articles/news-articles/2019/4/six-lawsuits-target-abbvies-humiraand-its-patent. Accessed August 17, 2020.

48. Hagen T. Biosimilar pipeline congested by patent litigation bottleneck. Center for Biosimilars. February 11, 2020. Available at: https://www. centerforbiosimilars.com/conferences/specialty-therapies-and-biosimilarsconference/onference-biosimilar-pipeline-congested-by-litigation-bottleneck. Accessed August 17, 2020.

49. U.S. Federal Trade Commission. Mallinckrodt will pay $\$ 100$ million to settle FTC, state charges it illegally maintained its monopoly of specialty drug used to treat infants. January 18, 2017. Available at: https://www.ftc. gov/news-events/press-releases/2017/01/mallinckrodt-will-pay-100-millionsettle-ftc-state-charges-it. Accessed August 17, 2020.

50. Healio Rheumatology. FDA approves Hadlima, fourth Humira biosimilar. July 24, 2019. Available at: https://www.healio.com/ rheumatology/rheumatoid-arthritis/news/online/\%7B8adlcdd9-05el-4036b6fa-706833f52b9d\%7D/fda-approves-hadlima-fourth-humira-biosimilar. Accessed August 17, 2020.

51. Brennan Z. U.S. biosimilar launches about to turn a corner. Regulatory Focus. March 16, 2020. Available at: https://www.raps.org/ news-and-articles/news-articles/2019/12/us-biosimilar-launches-about-toturn-a-corner. Accessed August 17, 2020

52. Zhai MZ, Sarpatwari A, Kesselheim AS. Why are biosimilars not living up to their promise in the US? AMA J Ethics. 2019;21(8):E668-78. doi:10.1001/amajethics.2019.668.

53. Brennan Z. Pfizer calls for FDA guidance to address false and misleading biosimilar ads. Regulatory Focus. August 28, 2018. Available at: https:// www.raps.org/news-and-articles/news-articles/2018/8/pfizer-calls-for-fdaguidance-to-address-false-and. Accessed August 17, 2020.

54. Mehr S. An interesting comparison: the latest data on US and EU biosimilar uptake. Biosimilars Review \& Report. April 23, 2020. Available at: https://biosimilarsrr.com/2020/04/23/an-interesting-comparison-thelatest-data-on-us-and-eu-biosimilar-uptake/. Accessed August 17, 2020.

55. Chen C. FDA increasingly approves drugs without conclusive proof they work. PBS. June 26, 2018. Available at: https://www.pbs.org/newshour/ health/fda-increasingly-approves-drugs-without-conclusive-proof-they-work. Accessed August 17, 2020

56. U.S. Food and Drug Administration. Third annual financial report: Prescription Drug User Fee Act of 1992. Fiscal Year 1995 Report to Congress. February 1, 1996. Available at: https://wayback. archive-it.org/7993/20170113031700/http://www.fda.gov/AboutFDA/ ReportsManualsForms/Reports/UserFeeReports/FinancialReports/PDUFA/ ucm135177.htm. Accessed August 17, 2020.

57. U.S. Department of Health and Human Services. Fiscal Year 2020 Food and Drug Administration. Justification of Estimates for Appropriations Committees. Available at: https://www.fda.gov/media/121408/download. Accessed August 17, 2020.

58. Darrow JJ, Avorn J, Kesselheim AS. FDA approval and regulation of pharmaceuticals, 1983-2018. JAMA. 2020;323(2):164-76. doi:10.1001/ jama.2019.20288.

59. U.S. Food and Drug Administration. Clinical trial endpoints for the approval of cancer drugs and biologics: guidance for industry. December 2018. Available at: https://www.fda.gov/media/71195/download. Accessed August 17, 2020.
60. Hwang TJ, Franklin JM, Chen CT, et al. Efficacy, safety, and regulatory approval of Food and Drug Administration-designated breakthrough and nonbreakthrough cancer medicines. J Clin Oncol. 2018;36(18):1805-12. doi:10.1200/JCO.2017.77.1592.

61. Kim C, Prasad V. Cancer drugs approved on the basis of a surrogate end point and subsequent overall survival: an analysis of 5 years of US Food and Drug Administration approvals. JAMA Intern Med. 2015;175(12):1992-93.

62. U.S. Food and Drug Administration. About FDA. What can the FDA do about the cost of drugs? October 29, 2019. Available at: https://www.fda. gov/about-fda/center-drug-evaluation-and-research-cder/frequently-askedquestions-about-cder\#16. Accessed August 18, 2020

63. Lau R, Stevenson F, Ong BN, et al. Achieving change in primary care-causes of the evidence to practice gap. Systematic review of reviews. Implement Sci. 2016;11:40. doi:10.1186/s13012-016-0396-4.

64. Cabana MD, Rand CS, Powe NR, et al. Why don't physicians follow clinical practice guidelines? A framework for improvement. JAMA. 1999;282(15):1458-65. doi:10.1001/jama.282.15.1458.

65. Morris ZS, Wooding S, Grant J. The answer is 17 years, what is the question: understanding time lags in translational research. J R Soc Med. 2011;104(12):510-20. doi:10.1258/jrsm.2011.110180.

66. Kalis JA, Pence SJ, Mancini RS, Zuckerman DS, Ineck JR. Prevalence of off-label use of oral oncolytics at a community cancer center. J Oncol Pract. 2015;11(2):e139-43. doi:10.1200/JOP.2014.001354.

67. Fairman KA, Davis LE, Sclar DA. Real-world use of PCSK-9 inhibitors by early adopters: cardiovascular risk factors, statin co-treatment, and short-term adherence in routine clinical practice. Ther Clin Risk Manag. 2017;13:957-65. doi:10.2147/TCRM.S143008.

68. Schutte T, Tichelaar J, Nanayakkara P, Richir M, van Agtmael M. Students and doctors are unaware of the cost of drugs they frequently prescribe. Basic Clin Pharmacol Toxicol. 2017;120(3):278-83. doi:10.1111/ bcpt.12678.

69. Allan GM, Lexchin J, Wiebe N. Physician awareness of drug cost: a systematic review. PLoS Med. 2007;4(9):e283. doi:10.1371/journal. pmed.0040283.

70. Arts DL, Voncken AG, Medlock S, Abu-Hanna A, van Weert HC, Reasons for intentional guideline non-adherence: a systematic review. Int J Med Inform. 2016;89:55-62. doi:10.1016/j.jimedinf.2016.02.009.

71. Makady A, Ham RT, de Boer A, Hillege H, Klungel O, Goettsch W. Policies for use of real-world data in health technology assessment (HTA): a comparative study of six HTA agencies. Value Health. 2017;20(4):520-32. doi:10.1016/j.jval.2016.12.003.

72. Keller F, Marczewski K, Pavlovic D. Physicians and pharmaceutical industry: need for transparency by conflict of interest declaration and independent ethical oversight. In: Clark P, ed. Bioethics - Medical, Ethical, and Legal Perspectives. IntechOpen; 2016. Available at: https://www. intechopen.com/books/bioethics-medical-ethical-and-legal-perspectives/ physicians-and-pharmaceutical-industry-need-for-transparency-by-conflictof-interest-declaration-and. Accessed August 18, 2020.

73. Brax H, Fadlallah R, Al-Khaled L, et al. Association between physicians' interaction with pharmaceutical companies and their clinical practices: a systematic review and meta-analysis. PLoS One. 2017;12(4):e0175493. doi:10.1371/journal.pone.0175493.

74. Tringale KR, Marshall D, Mackey TK, Connor M, Murphy JD, Hattangadi-Gluth JA. Types and distribution of payments from industry to physicians in 2015. JAMA. 2017;317(17):1774-84. doi:10.1001/ jama.2017.3091.

75. DeJong C, Aguilar T, Tseng CW, Lin GA, Boscardin WJ, Dudley RA. Pharmaceutical industry-sponsored meals and physician prescribing patterns for Medicare beneficiaries. JAMA Intern Med. 2016;176(8):1114-22. doi:10.1001/jamainternmed.2016.2765. 
76. Hartung DM, Johnston K, Cohen DM, et al. Industry payments to physician specialists who prescribe repository corticotropin. JAMA Netw Open. 2018;1(2):e180482. doi:10.1001/jamanetworkopen.2018.0482.

77. Herman B. The drug rebate curtain. Axios. April 2, 2018. Available at: https://www.axios.com/drug-rebate-curtain-express-scripts-d3c93f14-e6994a60-acld-9f8le5a658c0.html. Accessed August 18, 2020.

78. U.S. Government Accountability Office. Medicare Part D: use of pharmacy benefit managers and efforts to manage drug expenditures and utilization. July 2019. Available at: https://www.gao.gov/assets/710/700259. pdf. Accessed August 18, 2020.

79. Silverman E. Spread pricing: from largely unknown to much scrutinized and criticized. Managed Care. September 20, 2019. Available at: https://www. managedcaremag.com/archives/2019/9/spread-pricing-largely-unknownmuch-scrutinized-and-criticized. Accessed August 18, 2020.

80. Yost D. Ohio's Medicaid managed care pharmacy services. Auditor of State report. August 16, 2018. Available at: https://audits.ohioauditor.gov/ Reports/AuditReports/2018/Medicaid_Pharmacy_Services_2018_Franklin. pdf. Accessed August 18, 2020.

81. U.S. Department of Health and Human Services, Office of Inspector General. Medicaid MCO PBM pricing. February 2020. Available at: https://oig.hhs.gov/reports-and-publications/workplan/summary/ wp-summary-0000434.asp. Accessed August 18, 2020.

82. State of Massachusetts, Health Policy Commission. HPC datapoints: cracking open the black box of pharmacy benefit managers. June 5, 2019. Available at: https://www.mass.gov/doc/datapoints-issue-12-printableversion/download. Accessed August 18, 2020.

83. $3 \Delta$ XIS Advisors. Sunshine in the black box of pharmacy benefits management. Florida Medicaid pharmacy claims analysis. January 30, 2020. Available at: https://staticl.squarespace.com/static/5c326d5596e76f58ee 234632/t/5e384f26fc490b221da7cedl/1580748598035/FL+Master+ Final+Download.pdf. Accessed August 18, 2020.

84. Drugs.com. Duexis prices, coupons and patient assistance programs Available at: https://www.drugs.com/price-guide/duexis. Accessed August 18, 2020.

85. Calabrese D. Opinion: time to manage 'clinically superfluous' drug products to control costs. Managed Healthcare Executive. March 29, 2018. Available at: https://www.managedhealthcareexecutive.com/article/ opinion-time-manage-\%E2\%80\%98clinically-superfluous\%E2\%80\%99drug-products-control-costs. Accessed August 18, 2020.

86. Express Scripts. 2020 National Preferred Formulary exclusions. Available at: https://www.express-scripts.com/art/open_enrollment/ DrugListExclusionsAndAlternatives.pdf. Accessed August 18, 2020.

87. Grover N, Humer C. Horizon Pharma to pay Express Scripts $\$ 65$ million to settle rebate litigation. Reuters. September 29, 2016. Available at: https:// www.reuters.com/article/us-horizon-express-scripts-idUSKCN11Z1T3. Accessed August 18, 2020.

88. United States Securities and Exchange Commission. Horizon Pharma Public Limited Company. Regulation FD disclosure. December 15, 2016. Available at: https://www.sec.gov/Archives/edgar/data/1492426/000 119312516794633/d315384d8k.htm. Accessed August 18, 2020.

89. GoodRx. Ibuprofen and famotidine. Available at: https://www.goodrx. com/ibuprofen-and-famotidine/medicare-coverage. Accessed August 18, 2020

90. National Prescription Coverage Coalition. Lessons from Horizon Pharma: Stop covering Vimovo, Duexis and Pennsaid and stop relying on your PBM's "standard" formulary. 2014. Available at: https://nationalprescription coveragecoalition.com/lessons-from-horizon-pharma-stop-covering-vimovoduexis-and-pennsaid-and-stop-relying-on-your-pbms-standard-formulary/. Accessed August 18, 2020.

91. Humana. Drug list search for employer groups. Available at: https://druglist-search.apps.cf.humana.com/employer/check-coverage. Accessed August 18, 2020
92. Inserro A. FDA's Gottlieb blames rebates, reimbursement issues for holding back biosimilar market. AJMC.com. March 7, 2018. Available at: https://www.ajmc.com/newsroom/fdas-gottlieb-blames-rebatesreimbursement-issues-for-holding-back-biosimilar-market. Accessed August 18, 2020.

93. Sandburg B. Pfizer, Express Scripts clash over biosimilar formulary placement. Pink Sheet. May 13, 2019. Available at: https://pink. pharmaintelligence.informa.com/PS125269/Pfizer-Express-Scripts-ClashOver-Biosimilar-Formulary-Placement. Accessed August 18, 2020.

94. Tufts Center for the Study of Drug Development. Rapid growth in PBM exclusion lists poses challenge to drug developers. Impact Report. 2016;18(3).

95. Xolair (omalizumab) for subcutaneous use. Genentech. September 2014. Available at: https://www.accessdata.fda.gov/drugsatfda_docs/ label/2007/103976s5102lbl.pdf. Accessed August 18, 2020.

96. Nutropin AQ [somatropin (rDNA origin) injection]. Genentech. 2014. Available at: https://www.accessdata.fda.gov/drugsatfda_docs/ label/2014/020522s051lbl.pdf. Accessed August 18, 2020.

97. Gleason PP, Phillips J, Fenrick BA, Delgado-Riley A, Starner CI. Dalfampridine prior authorization program: a cohort study. J Manag Care Pharm. 2013;19(1):18-25. doi:10.18553/jmcp. 2013.19.1.18.

98. Keast SL, Holderread B, Cothran T, Skrepnek GH. Assessment of the effect of an enhanced prior authorization and management program in a United States Medicaid program on chronic hepatitis C treatment adherence and cost. J Am Pharm Assoc. 2018;58(5):485-91. doi:10.1016/j. japh.2018.06.013

99. No authors listed. AMCP Partnership Forum: optimizing prior authorization for appropriate medication selection. J Manag Care Spec Pharm. 2020;26(1):55-62. doi:10.18553/jmcp.2020.26.1.55

100. Burns J. The slow reveal. Managed Care. September 18, 2019. Available at: https://www.managedcaremag.com/archives/2019/9/slow-reveal. Accessed August 18, 2020.

101. Fein AJ. Employers slowly warm to point-of-sale rebates—but must move faster for insulin. Drug Channels. September 19, 2019. Available at: https://www.drugchannels.net/2019/09/employers-slowly-warm-to-point-ofsale.html. Accessed August 18, 2020.

102. Bai G, Socal MP, Anderson GF. Policy options to help self-insured employers improve PBM contracting efficiency. Health Affairs blog.

May 29, 2019. Available at: https://www.healthaffairs.org/do/10.1377/ hblog20190529.43197/full/. Accessed August 18, 2020.

103. Friedman S, Golden J. PBM contracting: are you playing with a full deck? Presentation at: 36th Annual Symposium of the International Society of Certified Employee Benefit Specialists. September 19, 2017. Available at: https://www.iscebs.org/Symposium/Documents/2017Sessions/Monday/6A_ PBM_Contracting_Are_You_Playing_With_a_Full_Deck.pdf. Accessed August 18, 2020.

104. Begley K. PBM contracting: tips, pitfalls, and opportunities. Presentation at: 62nd Annual Employee Benefits Conference. International Foundation of Employee Benefit Plans. November 2016. Available at: https://www.ifebp.org/ education/schedule/Documents/1601/H22_PBM_Contracting_Tips_Pitfalls_ and_Opportunities.pdf. Accessed August 18, 2020.

105. Fein AJ. Drug Channels news roundup, May 2019: Express Scripts' new GPO, more on Amazon/Pillpack, a BS update, and Vegas video. May 31, 2019. Available at: https://www.drugchannels.net/2019/05/drug-channelsnews-roundup-may-2019.html. Accessed August 18, 2020.

106. Health Rosetta. HRI benefits advisor compensation disclosure form. Available at: https://healthrosetta.org/learn/benefits-advisor-disclosure/. Accessed August 18, 2020.

107. Health Rosetta. Transparent pharmacy benefits. Available at: https:// healthrosetta.org/health-rosetta/transparent-pharmacy-benefits/\#details. Accessed August 18, 2020. 